\title{
Level I Nodal Positivity as a Factor for Involvement of the Submandibular Gland in Oral Cavity Carcinoma: A Case Series Report
}

\author{
Hamdan Ahmed Pasha ${ }^{1, *(1)}$ \\ Mumtaz Jamshed Khan 3,4 (1)
}

\author{
Rahim Dhanani ${ }^{1, *(\text { (D) }}$ \\ Shayan Khalid Ghaloo ${ }^{10}$ \\ Kulsoom Ghias ${ }^{2(1)}$
}

Address for correspondence Mumtaz Jamshed Khan, FACS, Department of Surgery, Aga Khan University, Karachi 74800, Pakistan (e-mail: khanm8@clevelandclinicabudhabi.ae).

\begin{abstract}
Keywords

- oral cavity

- carcinoma

- submandibular gland

- xerostomia

- neck dissection

Introduction The routine practice of neck dissection in the surgical management of oral carcinoma has evolved into a more functionally conservative approach. Over time, the rationale for removal of the submandibular gland has been questioned. Routine extirpation of the submandibular gland can aggravate the xerostomia experienced by many patients, significantly affecting their quality of life.

Objective The objective of the present study was to determine the incidence of submandibular gland metastases in oral cavity carcinoma and to identify possible factors that may affect their involvement.

Methods A total of 149 cases of oral carcinoma presenting at a private tertiary care hospital in Karachi, Pakistan, over the course of 1 year were reviewed retrospectively. Results Histopathological data showed that the submandibular gland was involved in $7(4.7 \%)$ cases. Involvement of level I lymph nodes was found in all of the cases. Direct extension of primary tumor was noted in two cases when the primary tumor was in the floor of the mouth.

Conclusion The results suggest that preservation of the submandibular gland during neck dissection for oral carcinoma can be practiced safely when there is no evidence of direct extension of the primary tumor toward the submandibular gland or when there is no clinical or radiological evidence of neck disease in level I. Presence of pathological lymph nodes in level I requires caution when contemplating preservation of the submandibular gland.
\end{abstract}

* These authors contributed equally to this work.

received

November 29, 2019

accepted

January 30, 2020

published online

June 30,2020
DOI https://doi.org/ 10.1055/s-0040-1709117. ISSN 1809-9777. (c) 2020. Fundação Otorrinolaringologia. All rights reserved.

This is an open access article published by Thieme under the terms of the Creative Commons Attribution-NonDerivative-NonCommercial-License, permitting copying and reproduction so long as the original work is given appropriate credit. Contents may not be used for commercial purposes, or adapted, remixed, transformed or built upon. (https://creativecommons.org/ licenses/by-nc-nd/4.0/)

Thieme Revinter Publicações Ltda., Rua do Matoso 170, Rio de Janeiro, RJ, CEP 20270-135, Brazil 


\section{Introduction}

Over time, the routine practice of neck dissection in the surgical management of oral carcinoma has moved toward a more functionally conservative approach. The earliest description of radical neck dissection as proposed by $\mathrm{Crile}^{1}$ has been replaced with selective cervical lymphadenectomy, addressing the earliest nodal basins and conservation of nonlymphatic structures like the sternocleidomastoid muscle, the internal jugular vein and the spinal accessory nerve. This is the result of an improved understanding of cervical nodal metastasis and the prognostic evidence supporting a conservative procedure. ${ }^{2-4}$

Removal of the submandibular gland in level I lymphadenectomy has been the standard. However, as functional dissection procedures evolve, the routine removal of the submandibular gland has been questioned. ${ }^{5,6}$ The submandibular gland contributes to the unstimulated production of saliva. ${ }^{7}$ Saliva plays an important role in the preparation of the food bolus, lubrication of masticated food, exerting an antimicrobial effect in the oral cavity and providing dental protection. ${ }^{8}$ Routine extirpation of the submandibular gland can aggravate the xerostomia experienced by a vast majority of head and neck cancer patients, particularly after adjuvant therapy. This results in dental caries, gingivitis, periodontitis and osteonecrosis. ${ }^{9}$ Pharmaceutical agents have had limited success in relieving xerostomia. ${ }^{7,10}$ The preservation of an uninvolved gland while ensuring a comprehensive clearance of level I lymph nodes appears to be a reasonable approach to address this issue.

In an anatomical and clinicopathological review of the lymphatics of the submandibular space in oral carcinomas, DiNardo proposed division of lymph nodes into six groups, namely preglandular, prevascular, retrovascular, retroglandular, intraglandular and deep submandibular. Regional metastasis was most commonly seen in the pre- and retrovascular group of nodes. No intraglandular nodes were identified in any of the clinical or cadaveric specimens, ${ }^{4}$ supporting the idea that there is no risk of leaving lymph nodes behind when sparing an uninvolved gland. Other studies have also shown that submandibular glands themselves do not contain lymph nodes ${ }^{4,11}$ and could be preserved without risking recurrence or survival. However, there is evidence that preserving the submandibular gland is not advisable in the floor of the mouth, in tongue cancers and in T2 lesions. ${ }^{12,13}$

The objective of the present study was to determine the incidence of submandibular gland metastases in oral cavity carcinomas and to identify possible factors that may influence its involvement. A secondary objective was to determine the frequency of residual neck disease at level I.

\section{Materials and Methods}

The present study received exemption from the institutional ethical review committee. A retrospective review of oral carcinoma cases operated at our center between February 2017 and January 2018 was performed. Patients with histopathologically confirmed squamous cell carcinoma of any of the subsites of the oral cavity who underwent primary surgical excision with ipsilateral and/or contralateral neck dissection with removal of at least one submandibular gland were included. Patients with a prior history of surgery, radiation or chemotherapy and those with histology other than squamous cell carcinoma were excluded. Medical records of 150 cases met the criteria.

In addition, the files of 36 patients, in whom level I dissection was performed leaving behind the submandibular gland, were also reviewed. These patients were followed-up for 6 months for any evidence of residual disease following preservation of the gland. Clinical examination and computed tomography (CT) scan done at the completion of treatment were used to evaluate the patients.

Data regarding age, gender, tumor site, neck nodal status and staging was collected. Postoperative histopathological reports were reviewed to record the involvement of the submandibular gland. The presence of lymph nodes within the gland and direct invasion of the gland were assessed. Patient data was analyzed using IBM SPSS Statistics for Windows, Version 23.0 (IBM Corp., Armonk, NY, USA). The Fischer exact test was applied to identify significant differences where relevant.

\section{Results}

During the study period of 1 year, 150 cases of oral carcinoma met the study inclusion criteria. One case was excluded from analysis due to a different final histology, leaving 149 patients. A total of 169 neck dissections were recorded as 20 patients underwent bilateral neck dissections. Of these 20 , the submandibular gland on the contralateral side was also excised in 8 patients, giving a total of 157 submandibular glands for evaluation.

There were 112 male (75.2\%) and 37 female (24.8\%) patients. The mean age was $47.6 \pm 12.8$ years old. The most common primary subsite was the buccal mucosa ( $n=94 ; 63.1 \%)$, followed by the tongue $(n=33 ; 22.1 \%)$, the gingiva $(n=8 ; 5.4 \%)$, the hard palate $(n=4 ; 2.7 \%)$, the retromolar trigone $(n=4 ; 2.7 \%)$, the lips $(n=3 ; 2.0 \%)$ and the floor of the mouth $(n=3 ; 2 \%)$. Patients most commonly presented with stage IV disease (55.7\%), followed by stage III (20.8\%), stage II (16.8\%) and stage I (6.7\%). Most patients presented with a T4a tumor $(n=60 ; 40.3 \%)$ (-Table 1$)$. Lymph node involvement was not found (pN0) in 79 (53\%) of patients. Neck metastasis was seen in $70(47 \%)$ of patients, with pN2b being the most common neck stage (26.8\%). Occult metastases were seen in 22 out of 82 necks (26.8\%).

Histopathology of the submandibular gland revealed that 7 out of 149 (4.7\%) ipsilateral submandibular glands were positive for metastases ( - Table 2 ). Of the 8 contralateral submandibular glands excised, none were positive.

Level I lymph nodes were positive in 47 out of 149 cases (31.5\%). All 7 patients with involvement of the submandibular gland had positive level I lymph nodes ( - Table 3 ). Of these 7 patients, two had a single positive node at level I while 5 had multiple level I positive nodes. None of the 79 patients with pNO necks had gland involvement. Using the Fisher exact test, this difference was found to be statistically significant $(p<0.01)$. 
Table 1 Tumor sites and T staging

\begin{tabular}{|l|l|l|l|l|l|}
\hline Site & $\begin{array}{l}\text { \# of } \\
\text { cases }\end{array}$ & T1 (\%) & T2 (\%) & T3 (\%) & T4 (\%) \\
\hline $\begin{array}{l}\text { Buccal } \\
\text { mucosa }\end{array}$ & 94 & $\begin{array}{l}7 \\
(7.4 \%)\end{array}$ & $\begin{array}{l}29 \\
(30.9 \%)\end{array}$ & $\begin{array}{l}14 \\
(14.9 \%)\end{array}$ & $\begin{array}{l}44 \\
(46.8 \%)\end{array}$ \\
\hline Tongue & 33 & $\begin{array}{l}4 \\
(12.1 \%)\end{array}$ & $\begin{array}{l}15 \\
(45.5 \%)\end{array}$ & $\begin{array}{l}13 \\
(39.4 \%)\end{array}$ & $\begin{array}{l}1 \\
(3 \%)\end{array}$ \\
\hline $\begin{array}{l}\text { Retromolar } \\
\text { trigone }\end{array}$ & 4 & - & $\begin{array}{l}2 \\
(50 \%)\end{array}$ & - & $\begin{array}{l}2 \\
(50 \%)\end{array}$ \\
\hline Gingiva & 8 & $\begin{array}{l}2 \\
(25 \%)\end{array}$ & $\begin{array}{l}2 \\
(25 \%)\end{array}$ & - & $\begin{array}{l}4 \\
(50 \%)\end{array}$ \\
\hline $\begin{array}{l}\text { Floor of } \\
\text { the mouth }\end{array}$ & 3 & - & - & - & $\begin{array}{l}3 \\
(100 \%)\end{array}$ \\
\hline Lips & 3 & - & - & $\begin{array}{l}1 \\
(33.3 \%)\end{array}$ & $\begin{array}{l}2 \\
(66.7 \%)\end{array}$ \\
\hline $\begin{array}{l}\text { Hard } \\
\text { palate }\end{array}$ & 4 & & $\begin{array}{l}4 \\
(100 \%)\end{array}$ \\
\hline Total & 149 & $\begin{array}{l}13 \\
(8.7 \%)\end{array}$ & $\begin{array}{l}48 \\
(32.2 \%)\end{array}$ & $\begin{array}{l}\mathbf{2 8} \\
(18.8 \%)\end{array}$ & $\begin{array}{l}60 \\
(40.3 \%)\end{array}$ \\
\hline
\end{tabular}

Table 2 Involvement of submandibular gland

\begin{tabular}{|l|l|}
\hline Total patients & 149 \\
\hline Neck dissections & \\
\hline Unilateral & 129 \\
\hline Bilateral & 20 \\
\hline Total submandibular glands excised & 157 \\
\hline Submandibular gland involved & \\
\hline Ipsilateral & 7 \\
\hline Contralateral & 0 \\
\hline Total (\%) & 7 (4.5\%) \\
\hline
\end{tabular}

With regards to the primary sub-sites of the 7 cases with involvement of the submandibular gland, 4 were from the buccal mucosa, 2 from the floor of the mouth and one from the gingivobuccal sulcus ( - Table 4 ). The two floor of the
Table 3 Level I positivity and submandibular gland involvement

\begin{tabular}{|c|l|l|l|}
\hline & \multicolumn{2}{|l|}{$\begin{array}{l}\text { Submandibular } \\
\text { gland involve- } \\
\text { ment }\end{array}$} & Total \\
\hline & Yes & No & \\
\hline Level I positive & & & \\
\hline Yes & 7 & 40 & 47 \\
\hline No & 0 & 102 & 102 \\
\hline Total & 7 & 142 & 149 \\
\hline
\end{tabular}

mouth cases were T4 and had direct extension of the tumor into the gland. The remaining 5 cases, that is, four buccal mucosa and one gingivobuccal sulcus, had positive periglandular lymph nodes with extension into the gland. These 5 cases had 3 or more positive lymph nodes in level I.

An independent set of 36 patients in whom the submandibular gland was preserved was followed up to 6 months for any residual or recurrent disease at level I. None of these patients had any evidence of residual or recurrent disease in the neck. The most common primary subsite amongst these was the buccal mucosa $(n=18 ; 50.0 \%)$ followed by the tongue ( $n=13 ; 36.1 \%)$, the gingiva $(n=4 ; 11.1 \%)$, and the floor of the mouth $(n=1 ; 2.8 \%)$. There were 9 patients with $\mathrm{N} 1$ neck disease confined to level I and 5 patients had N2 disease involving level I and II. None of these had extra capsular extension. The remaining 22 patients had N0 necks free of any disease on the final pathology ( - Table 5 ).

\section{Discussion}

In a neck dissection, whether selective, modified or radical, the excision of the submandibular gland is the standard while dissecting lymph nodes from level IB. The frequency of submandibular gland involvement in the literature ranges from 0.6 to $4.5 \%$ and has 3 mechanisms (-Table $\mathbf{6}$ ). There may be direct invasion of the gland by the tumor, invasion of the submandibular gland by metastatic lymph nodes in level I or by metastasis to intraglandular lymph nodes. Direct invasion by the tumor has been reported to be the most

Table 4 Mechanism of invasion

\begin{tabular}{|c|c|c|c|c|c|}
\hline Site & \# of cases & $\begin{array}{l}\text { Direct } \\
\text { invasion }\end{array}$ & $\begin{array}{l}\text { Invasion through } \\
\text { metastatic lymph node }\end{array}$ & $\begin{array}{l}\text { Metastasis to } \\
\text { submandibular gland }\end{array}$ & $\begin{array}{l}\text { Total submandibular } \\
\text { gland involvement }\end{array}$ \\
\hline Buccal mucosa & 94 & - & 4 & - & 4 \\
\hline Tongue & 33 & - & - & - & 0 \\
\hline Retromolar trigone & 4 & - & - & - & 0 \\
\hline Gingiva & 8 & - & 1 & - & 1 \\
\hline Floor of the mouth & 3 & 2 & - & - & 2 \\
\hline Lips & 3 & - & - & - & 0 \\
\hline Hard palate & 4 & - & - & - & 0 \\
\hline Total & 149 & 2 & 5 & 0 & 7 \\
\hline
\end{tabular}


Table 5 Regional recurrence according to $\mathrm{N}$ stage after preservation of the submandibular gland

\begin{tabular}{|l|l|l|}
\hline N Stage & \# of cases & Recurrence \\
\hline N0 & 22 & 0 \\
\hline N1 & 9 & 0 \\
\hline N2 & 5 & 0 \\
\hline Total & 36 & 0 \\
\hline
\end{tabular}

common method (- Table 6). In our study, the submandibular involvement was most commonly from metastatic level I lymph nodes invading the gland.

In a review of 107 head and neck cancer cases, Ebrahim et al found the submandibular gland to be involved in 1 case. $^{8}$ However, this study included a smaller number of oral cavity tumor cases (52), of which $8 \%$ had metastases up to level Ib. The single case in which the gland was infiltrated by tumor was a T3 buccal carcinoma that had gross involvement of the gland by direct spread of the tumor. Basaran et al studied 236 patients undergoing neck dissections for oral carcinoma and found 13 (5.5\%) of the glands involved. Direct invasion was again the most common mechanism in 8 out of the 13 positive glands. Four additional glands were infiltrated from metastatic paraglandular lymphadenopathy. Almost all of the cases in this series were tongue or floor of the mouth carcinomas. ${ }^{5}$ In another study from the region, a review of 98 specimens revealed involvement of the submandibular gland in 3 patients (3.06\%). Submandibular gland involvement was secondary to direct invasion in 2 cases where the primary lesion was in the tongue and in the floor of the mouth; both were T4N2B lesions. Involvement through metastatic periglandular lymph node was seen in 1 case of buccal mucosa tumor; also a T4N2b lesion. ${ }^{14}$

In our series, metastatic periglandular lymph node infiltration was more commonly encountered than direct tumor invasion. Direct invasion was seen in 2 of the 157 (1.3\%) glands. Tumors involving the floor of the mouth $(n=2)$ were the only cases that directly invaded the gland. In one of the largest series addressing submandibular gland infiltration in floor of the mouth carcinomas, a re-review of pathology slides from 51 floor of the mouth carcinoma cases was performed. ${ }^{15}$ Intraglandular lymph nodes were not found in any of 69 submandibular glands studied.

Junquera et al reported 31 cases of floor of the mouth squamous cell carcinoma with an incidence of ipsilateral level I metastasis of $31.7 \%$, but there were no cases of submandibular gland invasion. ${ }^{16}$ The authors therefore concluded that it is reasonable to preserve the gland when it is not directly infiltrated by the tumor. Here, 5 cases (3.2\%) are reported in which the gland was infiltrated by adjacent lymph node rather than tumor infiltration. This was the most common mechanism of spread of tumor in the current series. Of these 5 cases, 4 had $>3$ positive lymph nodes, whereas the remaining case had a single positive node at level Ib. Level I positivity also appears to be an important factor in determining the fate of the submandibular gland. Based on the results reported here, preoperative or intraoperative finding of enlarged level I nodes would be a good indicator for submandibular gland extirpation.

The presence of intraglandular lymph nodal metastasis has been controversial. ${ }^{17}$ Very few studies have reported this possibility. Chen et al reported one case of metastasis to the submandibular gland. ${ }^{18}$ Vaidya et al reported two cases, one of which was a tongue tumor, while the other was a palate tumor. ${ }^{19}$ In our study, intraglandular lymphoid tissue as a source of metastasis was not seen.

A major concern in submandibular gland-sparing neck dissection is leaving behind a metastatic lymph node, as nodal disease is a significant prognostic indicator of poor outcome. Chen et al reported survival rates for early T1 and T2 N0 oral carcinomas in patients with and without submandibular gland preservation. ${ }^{13}$ Although no statistical difference was found in the overall survival, there were only 10 patients with T2 oral carcinoma with preserved submandibular glands. Of these, 3 developed regional recurrence at level I and II, which may have been due to an inadequate nodal dissection. In our experience of 36 patients with submandibular gland preservation, there was no evidence of residual disease in the neck or early regional recurrence

In a series of 66 cases of tongue and floor-of-mouth cancers, Lanzer et al reported lymph node recurrence in

Table 6 Literature review of submandibular gland involvement according to mechanism

\begin{tabular}{|c|c|c|c|c|c|}
\hline \multirow[t]{2}{*}{ Authors } & \multirow{2}{*}{$\begin{array}{c}\text { Total \# of } \\
\text { submandibular } \\
\text { glands evaluated }\end{array}$} & \multirow{2}{*}{$\begin{array}{c}\text { Positive } \\
\text { submandibular } \\
\text { gland }\end{array}$} & \multicolumn{3}{|c|}{ Mechanism of submandibular gland involvement } \\
\hline & & & Tumor invasion & $\begin{array}{l}\text { Invasion by } \\
\text { metastatic } \\
\text { lymph node }\end{array}$ & $\begin{array}{c}\text { Metastasis to } \\
\text { submandibular gland }\end{array}$ \\
\hline Siegel et al $^{17}$ & 196 & 9 & 6 & 3 & - \\
\hline Chen et al ${ }^{18}$ & 383 & 7 & 5 & 1 & 1 \\
\hline Razfar et $a^{22}$ & 153 & 1 & 1 & - & - \\
\hline Byeon et $\mathrm{al}^{23}$ & 316 & 2 & 2 & - & - \\
\hline Basaran et al ${ }^{5}$ & 294 & 13 & 8 & 4 & 1 \\
\hline Current study & 157 & 7 & 2 & 5 & - \\
\hline
\end{tabular}


$28.5 \%$ of the patients with preserved submandibular glands. The study cohort largely comprised of T1 and T2 lesions with N0 necks. The authors postulated that although lymphatics develop after the submandibular gland is encapsulated, lymphatic vessels can adhere to the gland capsule and serve as a reservoir of cancer cells if the gland is preserved. ${ }^{20}$

The decision whether or not to excise the submandibular gland should be based on the proximity of the primary tumor to the gland and the status of level I nodes. ${ }^{21}$ As reported here, only cancers of the floor of the mouth had direct tumor invasion and there was no invasion of the submandibular gland in T1 and T2 lesions of other primary sites and in NO necks. Therefore, it would be prudent to excise the gland when there are adherent pathologic lymph nodes or a very close primary tumor.

\section{Conclusion}

Preservation of the submandibular gland during neck dissection in surgical management of oral carcinoma can be practiced safely when there is no evidence of direct extension of primary tumor toward the submandibular gland or when there is no clinical or radiological evidence of neck disease in level I. Presence of pathological lymph nodes in level I requires caution when contemplating preservation of the submandibular gland. Sparing the submandibular gland does not compromise oncologic clearance at level I, although additional studies are required to investigate the effects of submandibular gland preservation on survival and locoregional control of disease.

\section{Presented In}

Poster presentation at the American Head and Neck Society (AHNS) 2018 Annual Meeting held during the Combined Otolaryngology Spring Meetings (CSOM) on 18-19 April, 2018.

\section{Conflict of Interests}

The authors have no conflict of interests to declare.

\section{References}

1 Crile G. Excision of cancer of the head and neck. With special reference to the plan of dissection based on one hundred and thirty-two operations. J Am Med Assoc 1906;47(22):1780-1786

2 Shah JP, Candela FC, Poddar AK. The patterns of cervical lymph node metastases from squamous carcinoma of the oral cavity. Cancer 1990;66(01):109-113

3 Woolgar JA. Detailed topography of cervical lymph-note metastases from oral squamous cell carcinoma. Int J Oral Maxillofac Surg 1997;26(01):3-9

4 DiNardo LJ. Lymphatics of the submandibular space: an anatomic, clinical, and pathologic study with applications to floor-of-mouth carcinoma. Laryngoscope 1998;108(02):206-214

5 Basaran B, Ulusan M, Orhan KS, Gunes S, Suoglu Y. Is it necessary to remove submandibular glands in squamous cell carcinomas of the oral cavity? Acta Otorhinolaryngol Ital 2013;33(02):88-92

6 Takes RP, Robbins KT, Woolgar JA, Rinaldo A, Silver CE, Olofsson J, Ferlito A. Questionable necessity to remove the submandibular gland in neck dissection. Head Neck 2011;33(05):743-745

7 Jacob RF, Weber RS, King GE. Whole salivary flow rates following submandibular gland resection. Head Neck 1996;18(03): 242-247

8 Ebrahim AK, Loock JW, Afrogheh A, Hille J. Is it oncologically safe to leave the ipsilateral submandibular gland during neck dissection for head and neck squamous cell carcinoma? J Laryngol Otol 2011;125(08):837-840

9 Portenoy RK, Berger AM, Weissman DE. Principles and practice of supportive oncology. Lippincott-Raven; 1998

10 Fox PC, van der Ven PF, Sonies BC, Weiffenbach JM, Baum BJ. Xerostomia: evaluation of a symptom with increasing significance. J Am Dent Assoc 1985;110(04):519-525

11 Dhiwakar M, Ronen O, Malone J, Rao K, Bell S, Phillips R, et al. Feasibility of submandibular gland preservation in neck dissection: A prospective anatomic-pathologic study. Head Neck 2011; 33(05):603-609

12 Lanzer M, Gander T, Lübbers HT, Metzler P, Bredell M, Reinisch S. Preservation of ipsilateral submandibular gland is ill advised in cancer of the floor of the mouth or tongue. Laryngoscope 2014; 124(09):2070-2074

13 Chen TC, Lou PJ, Ko JY, Yang TL, Lo WC, Hu YL, Wang CP, et al. Feasibility of preservation of the submandibular gland during neck dissection in patients with early-stage oral cancer. Ann Surg Oncol 2011;18(02):497-504

14 Malgonde MS, Kumar M. Practicability of submandibular gland in squamous cell carcinomas of oral cavity. Indian J Otolaryngol Head Neck Surg 2015;67(01, Suppl 1):138-140

15 Fives C, Feeley L, Sadadcharam M, O'Leary G, Sheahan P. Incidence of intraglandular lymph nodes within submandibular gland, and involvement by floor of mouth cancer. Eur Arch Otorhinolaryngol 2017;274(01):461-466

16 Junquera L, Albertos JM, Ascani G, Baladrón J, Vicente JC. [Involvement of the submadibular region in epidermoid carcinoma of the mouth floor. Prospective study of 31 cases]. Minerva Stomatol 2000;49(11-12):521-525

17 Spiegel JH, Brys AK, Bhakti A, Singer MI. Metastasis to the submandibular gland in head and neck carcinomas. Head Neck 2004;26(12):1064-1068

18 Chen TC, Lo WC, Ko JY, Lou PJ, Yang TL, Wang CP. Rare involvement of submandibular gland by oral squamous cell carcinoma. Head Neck 2009;31(07):877-881

19 Vaidya AM, Vaidya AM, Petruzzelli GJ, McClatchey KD. Isolated submandibular gland metastasis from oral cavity squamous cell carcinoma. Am J Otolaryngol 1999;20(03):172-175

20 Guney E, Yigitbasi OG. Functional surgical approach to the level I for staging early carcinoma of the lower lip. Otolaryngol Head Neck Surg 2004;131(04):503-508

21 Barzan L, Antonio J, Santini S, Di RCarlo, Savignano MG, Politi D, et al. Submandibular approach and use of the harmonic instrument in lateral oral cavity and oropharyngeal oncologic surgery. Acta Otorhinolaryngol Ital 2010;30(06):277-280

22 Razfar A, Walvekar RR, Melkane A, Johnson JT, Myers EN. Incidence and patterns of regional metastasis in early oral squamous cell cancers: feasibility of submandibular gland preservation. Head \& Neck: Journal for the Sciences and Specialties of the Head and Neck. 2009;31(12):1619-1623

23 Byeon HK, Lim YC, Koo BS, Choi EC. Metastasis to the submandibular gland in oral cavity squamous cell carcinomas: pathologic analysis. Acta oto-laryngologica. 2009;129(01):96-100 